Joanna Ginter ${ }^{1}$

Uniwersytet Gdański

DOI: https://doi.org/10.26881/jsr.2021.16.01

\title{
NORMY POPRAWNOŚCIOWE DOTYCZĄCE LEKSYKI RELIGIJNEJ JAKO PRZEDMIOT ZAINTERESOWANIA KOREKTORÓW I REDAKTORÓW JĘZYKOWYCH
}

\section{Wprowadzenie}

Leksyka religijna, będąca jednym z najważniejszych wyznaczników języka religijnego (zob. Bajerowa 1994; Zdunkiewicz-Jedynak 2006, 2008) i występująca również $\mathrm{w}$ innych odmianach stylistycznych polszczyzny, podlega normom poprawnościowym; poszczególne formy wyrazowe, sformułowania i ich zapisy mieszczą się bowiem w normie językowej - tzn. „są w pewnym okresie uznane przez jakąś społeczność (najczęściej przez całe społeczeństwo, a przede wszystkim przez jego warstwy wykształcone) za wzorcowe, poprawne albo co najmniej dopuszczalne" (WSPP, s. 1626) - lub wykraczają poza tę normę. Językoznawcy zwracają uwagę na nieostrość pojęcia norma językowa i związane z tym problemy: (1) „W wielu wypadkach nie jest oczywiste, jakie formy są lub nie są «społecznie zaaprobowane»" (Puzynina 1998), ponadto (2) nie do końca wiadomo, kto ma decydować o tym, czy dany element językowy mieści się w normie, czy raczej należy go uznać za błąd językowy. $Z$ pierwszego problemu wynika podział normy na wzorcową (wysoką) i użytkową (zwyczajową, uzualną, potoczną w której mieszczą się również elementy dopuszczalne, mniej zalecane, ale wciąż uznawane za poprawne); z drugiego - podział na normę skodyfikowaną (spisaną w słownikach, poradnikach językowych, zaaprobowaną przez językoznawców) i nieskodyfikowaną (dotyczącą elementów pomijanych w publikacjach normatywnych, ale niepostrzeganych przez większość użytkowników języka za błąd i z tego powodu często utożsamianą z normą użytkową).

Na straży norm dotyczących leksyki religijnej, jako kodyfikator, stoi Zespół (do 2012 r. Komisja) Języka Religijnego Rady Języka Polskiego przy Prezydium PAN. Komisja ta wydała jak dotąd dwie publikacje o charakterze normatywnym: Zasady pisowni stownictwa religijnego (2004; dalej: ZPSR) oraz zaktualizowaną i rozszerzoną Pisownię słownictwa religijnego (2011; dalej: PSR), które stanowią

1 joanna.ginter@ug.edu.pl,https://orcid.org/0000-0002-6164-8367 
pokłosie ustaleń podjętych na jej posiedzeniach w latach 2003 (ZPSR) i 2010 (PSR), mających służyć ujednoliceniu i uściśleniu reguł pisowni leksyki religijnej oraz podporządkowaniu jej obowiązującym normom (zawartym w NSO 1999, a następnie w WSO 2010). Skodyfikowane zasady pisowni słownictwa religijnego dotyczą głównie pisowni wielką i małą literą; niewiele miejsca poświęcono innym problemom ortograficznym: pisowni skrótów i skrótowców oraz użyciu łącznika. Choć tytuły publikacji normatywnych (ZPSR, PSR) sugerują, że dotyczą one tylko pisowni, poza nią przedstawiono też - acz marginalnie - zagadnienia dotyczące poprawności słowotwórczej, wahania w odmianie wyrazów, błędne użycia słów i konstrukcji składniowych, poprawne użycie słów i wyrażeń. Taki rozkład treści wskazuje na to, że najbardziej kłopotliwym obszarem norm językowych jest dla użytkowników słownictwa religijnego ortografia ${ }^{2}$.

W niniejszym artykule chciałabym przedstawić problemy poprawnościowe w zakresie leksyki religijnej, które podczas opracowywania tekstów zgłaszają redaktorzy językowi i korektorzy, a więc świadomi użytkownicy języka - charakteryzujący się większą niż przeciętna znajomością normy językowej (a przynajmniej z racji wykonywanego zawodu predystynowani do takiej charakterystyki). Osoby odpowiadające za kształt językowy książek ogrywają ważną rolę w kształtowaniu świadomości językowej czytelników, przeciętny użytkownik języka czerpie bowiem wiedzę o tym, które jego elementy są poprawne, a które błędne, m.in. z lektury książek; uchodzą one za opracowane staranniej niż popularniejsze i łatwiej dziś dostępne źródła internetowe. Na osobach pracujących z tekstem spoczywa więc duża odpowiedzialność - i z tego powodu warto przyglądać się ich wyborom: sprawdzać, które obszary poprawności językowej sprawiają redaktorom i korektorom najwięcej trudności, które formy i konstrukcje uważają oni za poprawne i jako takie akceptują w opracowywanych przez siebie tekstach, które zaś odrzucają jako błędy (rzeczywiste lub domniemane) ${ }^{3}$.

Jako materiał źródłowy wykorzystuję wypowiedzi zamieszczone w grupie dyskusyjnej Redaktorzy, korektorzy, edytorzy - taczcie się. ${ }^{4}$ na portalu społecznościowym Facebook. Ta zamknięta grupa, założona w 2013 r., jest ,skierowana do tych, którzy zajmują się pracą z tekstem" - do szukających pracy w zawodzie korektora/redaktora oraz potrzebujących ,porady od kolegów po fachu”. Obecnie liczy ona ponad 15 tys. członków, choć w pierwszych latach działalności była dużo skromniejsza. W tak licznym gronie tytułowi redaktorzy, korektorzy i edy-

${ }^{2} \mathrm{Na}$ temat pisowni słownictwa religijnego w kontekście PSR i ZPSR (na materiale z poradni językowych) - zob. też Ginter 2015.

${ }^{3}$ Kwestię problemów (wykraczających poza leksykę religijną), z jakimi mierzą się redaktorzy, podjęłam też m.in. w artykule: Ginter 2013.

${ }^{4}$ https://www.facebook.com/groups/478873322210758. Dostęp do wszystkich źródeł internetowych: 1.03.2021. 
torzy (tj. wydawcy, osoby zajmujące się składem tekstu itp.) stanowią zapewne mniejszość, ale to właśnie oni są aktywnymi członkami grupy; poza nimi są tu studenci edytorstwa, autorzy szukający redaktora/korektora do swojego tekstu, tłumacze, a także osoby przyglądające się grupie biernie - a więc miłośnicy języka niebędący specjalistami lub wykonujący inne zawody związane z językiem (np. nauczyciele poloniści, dziennikarze, językoznawcy akademicy). Pytania na forum pojawiają się prawie każdego dnia, zazwyczaj po kilka dziennie, z czego znakomita większość dotyczy problemów językowych; pytający chcą rozwiać wątpliwości, które nasuwają się im podczas pracy. W tym miejscu warto zauważyć, że redaktorzy i korektorzy często pracują z tekstem samodzielnie, $\mathrm{w}$ domu, nie mają wokół siebie współpracowników, z którymi mogliby się skonsultować, dlatego istnienie takiej grupy wydaje się jak najbardziej uzasadnione i pożyteczne.

Członkowie tej samopomocowej społeczności niejednokrotnie zastanawiali się nad poprawnością jednostek, które można zaliczyć do leksyki religijnej. Niestety publikowane przez nich posty nie są w żaden sposób porządkowane (jak dzieje się to $\mathrm{np}$. w internetowych poradniach językowych, gdzie problemy są przypisywane do poszczególnych działów tematycznych typu ortografia czy fleksja), co znaczenie utrudnia dotarcie do wszystkich interesujących nas wpisów. Na potrzeby artykułu przyjęłam więc, że analizie poddane zostaną te posty, które Facebook zwróci po wpisaniu w wyszukiwarkę grupy słowa religijny (w różnych formach fleksyjnych), występującego albo bezpośrednio w pytaniu (w poście), albo w odpowiedziach na nie (w komentarzach). Niektóre z wyników wyszukiwania zostały odrzucone ze względu na to, że odbiegały od założonej tematyki (nie dotyczyły poprawności językowej - np. oferty pracy nad tekstami religijnymi). Choć trzon analizy stanowiły posty (z informacją o redaktorskich wątpliwościach), w artykule odnoszę się również do komentarzy zawierających propozycje rozwiązania problemów i pewne informacje o tym, jaki stosunek do leksyki religijnej mają redaktorzy.

\section{Problemy zgłaszane przez redaktorów i korektorów}

Większość analizowanych pytań dotyczy pisowni wielką i małą literą - a więc tego, co w PSR/ZPSR uznano za obszary najbardziej problematyczne. Redaktorów interesuje użycie wielkich liter ze względów nie tylko znaczeniowych (o których dalej), lecz także grzecznościowo-uczuciowych, o czym świadczą pytania o zapis zaimków odnoszących się do Boga - np.: „Wielką czy małą byście [je] pisali? Przykład: Dzięki (M)nie twe oczy widza, dzięki (M)nie twe uszy stysza, nie mów, że znasz tajemnice, ty sam jesteś tajemnica” (9.08.2020); „Czy w pracy naukowej zaimek odnoszący się do Boga także powinien być pisany wielką literą?” (21.12.2018); „Bóg przyjąt go do siebie. Bóg przyjąt go do Siebie. 
Który wariant?” (15.09.2016); „[...] Jemu, o Nim, Go - wiadomo. Aż tu nagle czytam: Chrystus z wizji Faustyny to jedno, a Ten tutejszy - drugie. Ten czy ten?" (14.08.2015). Jak widać, pytania nie dotyczą zwykłych zaimków osobowych czy dzierżawczych skierowanych do drugiej osoby (w tym wypadku - do Boga), lecz użyć szczególnych: gdy chodzi o zaimek zwrotny (tu o formę siebie); gdy zapisano słowa Boga mówiącego o samym sobie (mnie); gdy nie wiadomo, czy zaimek odnosi się do Chrystusa jako osoby, czy tylko do jego pewnego wyobrażenia; gdy rzecz dotyczy stylu naukowego, a nie języka religijnego (w którym pisownia tych zaimków byłaby jak najbardziej uzasadniona). Pytania te są więc motywowane wątpliwością: czy w takich szczególnych sytuacjach pisownia wielką literą ze względów grzecznościowo-uczuciowych nie jest przesadą, nadużyciem zasady 19 WSO, według której „Użycie wielkiej litery ze względów uczuciowych i grzecznościowych jest indywidualną sprawą piszącego".

Obawami przed ewentualnym nadużyciem wielkiej litery są również motywowane wątpliwości w zakresie użycia wielkich i małych liter ze względów znaczeniowych. Wiele z problemów wynika z polisemii: dany wyraz $(\mathrm{M} / \mathrm{miko-}$ taj-13.11.2020; $\dot{Z} / \dot{z} y d-15.10 .2020 ;$ B/bóg - 26.07.2019) ma kilka znaczeń, przy czym tylko w niektórych powinien być zapisywany wielką literą; redaktorzy zgłaszają problemy z identyfikacją znaczenia. Zastanawiają się też, czy w pewnych wypadkach uzasadniona jest pisownia wielką literą wyrazów rozpoczynających się zazwyczaj literą małą: „Mam niejasność co do pisowni zły jako synonimu szatana, siły nieczystej. Zostawilibyście w tekście pisane małą literą?" (12.05.2018); i przeciwnie - czy można zapisać małą literą nazwy zwykle zapisywane wielką: „Ja w poniższym zdaniu doszłam do wniosku, że Matka Teresa funkcjonuje jako figura, dlatego zapisałam zdanie w ten sposób: Może więc stać się dla nich matką teresa? [...] chciałabym jednak potwierdzić, że w przenośnym użyciu imienia i nazwiska stosujemy małą literę” (8.07.2020); ,[...] anioł zawiadamia o Bożym narodzeniu. Czy tutaj słusznie zostawiłam małą literę w słowie narodzeniu? [...]" (22.11.2015). Autorka pytania o zapis nazwy Z/zły zna zasadę pisowni 18.3 [60], zgodnie z którą ,,wielką literą piszemy imiona własne bogów oraz jednostkowych istot mitologicznych" (WSO 2010/2016), a autorka pytania o M/matkę T/teresę - zasadę 20.23 [122], mówiącą, że „małą literą piszemy rzeczowniki utworzone od nazw własnych ludzi oraz istot mitologicznych, używane w znaczeniu pospolitym" - obie redaktorki zastanawiają się jednak, czy regułom tym podlegają konkretnie przykłady.

Stosunkowo dużo pytań dotyczy pisowni słowa święty - będącego przymiotnikiem stojącym przy imieniu osoby kanonizowanej, np. Święta Katarzyna, Święta Barbara (21.02.2020), oraz pojedynczym leksemem oznaczającym osobę kanonizowaną, np. w wypowiedzeniach: Stary święty patrzy na nas z marsowa mina (14.06.2020) oraz Niech nas święci pańscy chronia (4.02.2021). Wątpliwości biorą się tu nie tylko z wieloznaczności (czy wielofunkcyjności) tego 
wyrazu, lecz także z faktu, że przepisy regulujące jego pisownię zmieniły się w ostatnich czasach, przez co wiele źródeł, z których korzystają redaktorzy, jest ze sobą sprzecznych (nieaktualne zalecenia $w$ internetowych poradniach językowych, NSO, WSO 2003/2006/2010 vs aktualne porady, ZPSR/PSR i WSO 2016). Przypomnijmy w tym miejscu, że w WSO 2010 przy haśle święty zamieszczono przykłady: Święty Mikołaj i święty Piotr (bez wyjaśnienia powodów różnicy w pisowni), a w WSO 2016 - Święty Michat, Święty Piotr, Święta Kinga 5 .

Do budzących wątpliwości antroponimów można również zaliczyć nazwy członków zakonów: „Elżbietanki z małej litery, a siostry elżbietanki czy siostry Elżbietanki?" (30.08.2016), które znów pokazuje, że redaktorka - chociaż zna regułę (pisownia nazw członków zakonów małą literą) - dopuszcza możliwość, iż w niektórych sytuacjach (tu: z połączeniem z innym wyrazem) może ona nie być właściwa.

Pisownia nazw zakonników budzi jeszcze więcej wątpliwości, gdy są one de facto częścią nazw zakonów:

Pisownia wielką/małą literą. Pełna nazwa bonifratrów to Zakon Szpitalny św. Jana Bożego. Co w przypadku, gdy występuje w tekście zakon bonifratrów albo zakon szpitalny? Podobnie: Polska Prowincja Zakonu Bonifratrów czy polska prowincja zakonu bonifratrów? [...] (8.01.2020),

których to nazw dotyczy również pytanie: ,[...] zakon krzyżacki - to jasne. Ale: stosunki króla polskiego z Zakonem czy z zakonem?” (14.03.2019). Autorka pierwszego z tych pytań zastanawia się, czy rozszerzyć pisownię wielkoliterową na skróconą nazwę zakonu oraz na jednostkę administracyjną, a więc na onimy zapisywane według reguł ogólnych małą literą; autorka drugiego pytania dopuszcza możliwość wprowadzenia wielkiej litery do skróconej nazwy obiektu, którego pełna nazwa zapisywana jest małą literą - oba te pytania świadczą więc o pewnej skłonności do (nad)używania wielkich liter.

Pytania o użycie wielkiej litery dotyczą też takich chrematonimów, jak tytuły: E/encyklika „Deus caritas est” (11.10.2016), D/dziesięć (D/dziesięcioro) P/przykazań, D/dekalog (17.07.2018) i quasi-tytuły: Koronacja C/cudownego O/obrazu Matki Boskiej (8.07.2018); nazwy sakramentów: S/sakrament P/pokuty i P/pojednania" (5.04.2020); nazwy wydarzeń: R/reformacja (2.04.2017); nazwy świąt: Ś/środa P/popielcowa (26.11.2017), także Ś/śsięta (w domyśle: Bożego Narodzenia - 12.11.2020). Ponadto grupowiczów interesowały: zapis przymiotnika M/maryjny w wyrażeniu objawienia M/maryjne (13.01.2017; wątpliwość wzięła się zapewne z trudności w ustaleniu, czy jest to przymiotnik dzierżawczy, czy jakościowy), pisownia nazwy K/kuria R/rzymska (7.01.2017;

\footnotetext{
${ }^{5} \mathrm{Na}$ temat pisowni przymiotnika święty - zob. też Ginter 2012.
} 
którą aktualny w chwili zadania pytania WSO 2010 pozwalał zapisywać wariantywnie), zapis nazwy P/poznańska S/skałka (10.09.2018) nawiązującej do krakowskiego kościoła Na Skałce.

Drugi obszar ortografii - pisownia łączna, rozdzielna i z łącznikiem - jest w pytaniach redaktorów i korektorów reprezentowana właściwie tylko przez pojedynczy problem: Nowo+narodzony (w odniesieniu do Chrystusa). Pytający zna normę, ale się z nią nie zgadza, o czym świadczy sposób sformułowania pytania: „Czy P.T. Korektorzy odważyliby się napisać w świątecznych życzeniach Nowonarodzony? Łącznie? Narażając się na krytykę, że popełnili błąd ort.?" (16.11.2018).

Więcej wątpliwości wzbudziło tworzenie skrótów - od: Jego Eminencja ksiądz kardynat Kazimierz Nycz i Jego Ekscelencja ksiadz biskup Edward Dajczak (10.06.2018); kościót św. Stanisława Biskupa i Męczennika (2.03.2016); Matka Boska Bolesna (22.11.2017); święci (8.05.2018); rzymskokatolicki (13.09.2016).

Poza ortografią pytania dotyczyły edytorstwa - wyboru między antykwą a kursywą w tytułach ksiąg biblijnych (7.06.2017 i 27.10.2019) i zapisu nazwiska autora (papieża Franciszka) w bibliografii (2.01.2017); leksyki i semantyki łączliwości leksykalnej (papież urzędujący czy panujący - 6.12.2019), frazeologii (czy sakramenty wyciskaja znamię - 16.01.2018), relacji między wyrazami (o antonim przymiotnika katolicki - 7.05.2017), podejrzenia nadwyżki semantycznej (msza św. pogrzebowa czy tylko msza pogrzebowa? - 19.09.2016), słowotwórstwa (nazwa wyznawcy ewangelikalizmu - 2.09.2019); fleksji (odmiana wyrazu dobro - 12.11.2016).

\section{Źródła normy językowej przywoływane przez redaktorów}

Sposób sformułowania wyżej przytoczonych pytań świadczy o tym, że ich autorzy mają ogólną wiedzę na temat norm językowych oraz źródeł, w których można te normy znaleźć, niezbędną do wykonywania zawodów redaktora językowego i korektora. Przed zadaniem pytania na forum często próbują rozstrzygnąć swoje wątpliwości samodzielnie, poszukują odpowiedzi w słownikach, archiwach poradni językowych lub PSR, o czym informują innych członków grupy. Pytanie zadają, gdy nie znajdują zadowalającej ich odpowiedzi (np. dlatego że „Pisownia słownictwa religijnego milczy" - 10.09.2018) lub znalezione w różnych źródłach odpowiedzi, według nich, się wykluczają (np. „W poradniach językowych jest prawdziwy kogel-mogel [...], dlatego pozostaje mi zapytać tutaj [...]" (4.02.2021).

$\mathrm{Z}$ jednej strony redaktorzy zachowują ograniczone zaufanie wobec uzusu niemającego wyrażonej explicite aprobaty językoznawców („w internecie częściej pojawia się pierwsza wersja, ale dużo tego nie jest, a źródła takie sobie..." 10.09.2018; „Gazety uparcie piszą szpital Bonifratrów, a wg mnie to najgorsza 
wersja” - 21.03.2016; „Tak twierdzi wikipedia, ale jakoś nie chce mi się w to wierzyć" - 2.09.2019); z drugiej - nie zawsze mają świadomość hierarchii źródeł językoznawczych, „ufając” jednakowo wszystkim tym źródłom i uważając za „kogel-mogel” sytuację, gdy pojawiają się między nimi rozbieżności. Widać to m.in. w wypowiedzi:

Wg 2 słowników ortograficznych, które mam w domu - małą. Wg Komisji Języka Religijnego Rady Języka Polskiego przy Prezydium PAN wielką. W skład tej komisji wchodził m.in. redaktor jednego z tych słowników :D I co ja mam biedna zrobić [...]? (26.11.2017).

Redaktorka nie ma świadomości, że normy w zakresie pisowni oparte na zasadzie konwencjonalnej mogą ulec zmianie (zapis Środa Popielcowa, którego dotyczy pytanie, pojawił się po raz pierwszy w WSO 2006 pod wpływem nowo wydanych ZPSR; w WSO 2003 i wcześniejszych słownikach zanotowano: środa popielcowa - pytająca korzystała zapewne ze słowników wydanych przed 2006 r.). Zdarza się ponadto, że przy ustalaniu pisowni redaktorzy przekładają słowniki opisowe nad normatywne, np. „Jak napisalibyście wyrażenie kuria rzymska? Sądząc z http://sjp.pwn.pl/sjp/kuria-rzymska;2476675.html - mała, ale również w PWN widziałam gdzieś wielkie litery" (7.01.2017); podany link prowadzi do słownika języka polskiego, mimo że pisownia wyrażenia kuria rzymska jest skodyfikowana w dostępnym na tej samej stronie internetowej WSO (https:// sjp.pwn.pl/so/kuria;4456439.html) ${ }^{6}$.

Redaktorzy korzystają też z pomocy grupy, gdy nie mają dostępu do źródła, którym chcieliby się posłużyć [np. „Zasady słownictwa religijnego zgubiłam jakiś czas temu, może ktoś ma na wierzchu (choć nie pamiętam, czy tam to było)" - 2.03.2016], kiedy nie są pewni, jak rozumieć znalezioną w innym miejscu informację na temat normy (np. „czy ma tutaj zastosowanie porada dra Jana Grzeni - gdzie chodzi o dziecko?" - 25.02.2016), lub gdy potrzebują dodatkowej opinii, bo przykład nie jest oczywisty w świetle zasad (np. 15.10.2020). Czasem pytający chce sprawdzić uzus, poznać preferencje innych kompetentnych osób zwłaszcza w wypadku normy wariantywnej (np. „Znam zasady, chodzi mi tylko o to, którą formę byście wybrali” - 8.05.2018; „To nie jest pytanie o regułę, tylko o Wasze indywidualne spojrzenia w sytuacji, w której norma dopuszcza dowolność” - 9.08.2020) lub rozbieżności między normą językową (ortograficzną) a edytorską (czy szerzej - między normą a uzusem):

${ }^{6}$ Przywołanie SJP zamiast WSO tłumaczyć też można faktem, że po wpisaniu wyrażenia kuria rzymska w wyszukiwarkę na stronie sjp.pwn.pl otrzymamy wynik wyłącznie w SJP; w WSO zapis kuria rzymska // Kuria Rzymska znajduje się pod hasłem kuria. 
Słownik ortograficzny PWN zaleca skrót rzymskokat., a Wolański pisze u siebie: „W zastosowaniach typowo ortograficznych łącznika używa się [...] w skrótach od złożeń przymiotnikowych niezawierających w pełnej formie łącznika, np. rz.-kat. lub rzym.-kat. (= rzymskokatolicki) [...]" (s. 52-53). Co o tym sądzicie? [...] (13.09.2016).

\section{Stosunek redaktorów do pisowni słownictwa religijnego}

Redaktorzy zdają sobie sprawę ze specyfiki języka religijnego i dopuszczają możliwość, że dotyczące go normy mogą być nieco inne niż te, które odnoszą się do polszczyzny ogólnej czy jej innych odmian stylistycznych (np. „Czy [...] w przypadku specyficznego języka taka forma dobra jest akceptowalna?” 12.11.2016). Jako grupa zawodowa wiedzą o istnieniu PSR i - w miarę możliwości - chętnie z niej korzystają; wymieniają to źródło nie tylko w samych pytaniach (postach), lecz także w odpowiedziach (komentarzach), jeśli nie przywołał go wcześniej pytający, np.: „Przy okazji polecam: [link do książki Pisownia stownictwa religijnego na stronie wydawnictwa Biblos - przyp. J.G.]. Niedroga rzecz, a pomaga [...]" (4.02.2021).

Stosunkowo dużo odpowiadających poleca też ZPSR (np. 30.08.2016) lub powołuje się na nie w odpowiedziach (np. 22.11.2017) - dlatego że są one, przynajmniej w okrojonej wersji, łatwo dostępne w Internecie na stronie Katolickiego Uniwersytetu Lubelskiego. Wydaje się więc, że wielu redaktorom brakuje świadomości, iż ZPSR to źródło nieaktualne, zastąpione już 10 lat temu przez PSR, i niektóre kwestie (np. pisownię nazw 7 bazylik większych) regulujące inaczej niż nowsza publikacja.

Autorzy analizowanych tu pytań w zdecydowanej większości pozostają neutralni wobec norm poprawnościowych dotyczących leksyki religijnej. Tylko nieliczni sygnalizują negatywny stosunek do niektórych wyrażeń i zwrotów (np. „W tekstach kościelnych nierzadko pojawia się dość makabryczna, moim zda$\underline{\text { niem}}^{7}$, konstrukcja: wyciskać znamię" - 16.01.2018) lub zapisów, przekładając nad nie względy merytoryczne (np. „Niezależnie, co o tym myślę, wiem, że piszemy Święty Jan, Błogosławiony Jerzy itd.” - 14.06.2020). Na tym tle wyjątkowy charakter ma emocjonalna wypowiedź:

Czy ja już postradałem zmysł językowy, czy redakcja i korekta jest do bani?

Redaktor główny oddaje mi przełożony tekst teologiczny - pisząc, że tekst przejrzało 4 (!) redaktorów merytorycznych i dwóch polonistów (!) - i ku mojemu zdumieniu zaimki dzierżawcze „swój” stosowane względem Boga

${ }^{7}$ Wszystkie podkreślenia w cytatach pochodzą od autorki artykułu. 
kropnął mi na wielkoliterowe. Koszmar zaczyna się już od pierwszego zdania: „Bóg objawił prorokom siebie samego i Swoją wolę w ściśle określonych, prawdziwych twierdzeniach i za pośrednictwem Swego Ducha".

Zdycham (24.05.2016).

Negatywnie nacechowane sformułowania (,postradałem zmysł”, „,do bani”, „zdycham”), pejoratywne kolokwializmy (,kropnął”) oraz wykrzykniki w nawiasie mające służyć nie tyle zwróceniu na coś uwagi, ile wyrażeniu oburzenia jednoznacznie wskazują na to, że autor pytania (tym razem jest nim nie redaktor/ korektor, lecz tłumacz - a więc również osoba pracująca z tekstem) nie akceptuje pisowni wielką literą zaimków odnoszących się do Boga - nawet w „tekście teologicznym", a więc w sytuacji, gdy jest to uzasadnione ortografią szacunku. Taki sposób sformułowania posta sprowokował czytelników do dyskusji w komentarzach; pojawiają się w niej zarówno głosy aprobaty wobec autora, zwłaszcza żartobliwe (np. „Pogódź się z tym, a będzie ci to policzone na sądzie ostatecznym"), jak i wypowiedź przeciwna:

Otóż przyjmij do wiadomości, że w pewnych tekstach chrześcijańskich zaimki odnoszące się do Boga pisze się często wielką literą. Na znak szacunku do Boga. Jeśli nie potrafisz tego uszanować, to może powinieneś poinformować o tym pracodawcę, który weźmie sobie mniej sfrustrowanego zleceniobiorcę (25.05.2016).

W przeciwieństwie do samych postów - w komentarzach, czyli odpowiedziach na post ze zgłoszonym problemem, znajdziemy sporo opinii (często ironicznych) zdradzających stosunek redaktorów do języka religijnego i jego norm. Komentującym nie podobają się zwłaszcza zalecenia dotyczące pisowni wielką i małą literą, w pewien sposób „faworyzujące” wielką literę - i nie dotyczy to wyłącznie pisowni ze względów grzecznościowo-emocjonalnych, będących przecież kwestią uznaniową [np. ,Jasne, można jeszcze wersalikami i boldem (bo jak nie, to pójdziesz do piekła)" - 15.09.2016 ${ }^{8}$, lecz także użycia wielkiej litery ze względów znaczeniowych (np. „To jakieś dziwactwo. Dlaczego ma być Święty Michat, a nie święty Michat?”- 4.02.2021). Niektórzy komentujący sprzeciwiają się stawianiu PSR nad innymi normami poprawnościowymi (WSO), a więc pewnemu uprzywilejowaniu słownictwa religijnego:

${ }^{8}$ Komentarz ten otrzymał 15 ,polubień”, tzn. 15 osób wyraziło jego aprobatę przez naciśnięcie przycisku „Lubię to”. To stosunkowo duża liczba, jeśli wziąć pod uwagę reakcje na inne komentarze zamieszczane pod postami w badanej grupie dyskusyjnej. 
W tej ekspertyzie najbardziej podoba mi się zdanie: „W przypadku pisowni słownictwa religijnego przyjęto zasadę pierwszeństwa reguł, zawartych w publikacji Pisownia stownictwa religijnego pod red. Renaty Przybylskiej i ks. Wiesława Przyczyny, nad zasadami obowiązującymi w słownikach ortograficznych". Nawet tutaj! (22.02.2017).

\section{Postawy wobec języka i roli redaktora/korektora w nadawaniu ksztaltu tekstowi}

Analiza materiału wykazała, że redaktorzy prezentują zaangażowane postawy wobec języka, co nie powinno dziwić, zważywszy na wykonywany przez nich zawód i fakt zadawania pytania, a więc zainteresowanie normą językową. Dobrze widoczny jest perfekcjonizm, wyrażający się ,w dążeniu do tego, by elementy językowe były używane precyzyjnie i jednoznacznie, [...] żeby ograniczyć liczbę wyjątków, zmniejszyć wariantywność i wszelką nieregularność w obrębie systemu językowego” (Markowski 2009, s. 132). „Chyba powinna być jakaś konsekwencja i jeden zapis" (13.11.2020) - uważają redaktorzy i korektorzy, niechętni wariantom ortograficznym. Nie mniej dostrzegalna jest skłonność tych osób do logizowania (np. „Mała litera wydaje mi się sensowniejsza” - 26.07.2019; „Skoro rzeczownik tak, to zaimek chyba też, ale wolę się upewnić” - 21.12.2018), nie obserwujemy za to - przynajmniej w samych postach - skłonności do puryzmu językowego; nie licząc posta z 24.05.2016 r., redaktorzy kierują się przede wszystkim przesłankami rozumowymi, a nie emocjonalnymi. Dużą rolę przywiązują do uzusu, niekoniecznie znormalizowanego i skodyfikowanego (np. „Pisanie tych zaimków wielką literą widzę tylko w tekstach religijnych, pisanych przez wierzących dla wierzących" - 28.07.2016), a także do kontekstu, który może decydować o pisowni.

W analizach dotyczących postaw redaktorów wobec opracowywanych tekstów (nie tylko religijnych) niepokoić może pewna skłonność do przekładania własnych preferencji nad wybory autorów. W tym kontekście optymizmem napawają komentarze, których autorzy zwracają uwagę na służebną wobec tekstu (i autora) rolę redaktora - np. w odpowiedzi na pytanie o zapis w tekście naukowym zaimka odnoszącego się do Boga:

Obowiązuje pisownia wariantywna niezależnie od rodzaju tekstu i jego tematyki. Autor może wybrać sam i to naturalne, że dokonuje tego wyboru przeważnie pod wpływem własnych przekonań religijnych. Nie wyobrażam sobie, żebym jako redaktor w tym przypadku mogła narzucać swoją wolę, nie mając oparcia w zasadach, tylko w światopoglądzie (21.12.2018). 
Poza punktem widzenia autora redaktor powinien uwzględniać jeszcze perspektywę czytelnika. Można założyć, że każda prośba o pomoc wyrażona na forum redaktorsko-korektorskim jest podyktowana - chociaż w jakimś stopniu myślą o czytelniku; chęcią sprawienia, by tekst był dla niego zrozumiały, przyjemny w lekturze, odbiorze. W analizowanych postach odniesienie się explicite do osoby czytelnika pojawia się tylko w jednej wypowiedzi: „Autor stwierdza, że przeciętny czytelnik będzie zaskoczony użyciem małych liter ;) Nie uważam, aby profesjonalnym było sugerowanie się przeciętnym czytelnikiem [...]" (8.07.2020). Ta wypowiedź redaktorki, która chce użyć w tekście zapisu matka teresa, pokazuje przywiązywanie dużej wagi do zasad pisowni, także tych raczej nieznanych przeciętnemu użytkownikowi języka i niezgodnych z uzusem świadczy to bowiem o profesjonalizmie redaktora; ponieważ jednak taka wypowiedź ma jednostkowy charakter, nie należy wysnuwać na jej podstawie zbyt daleko idących wniosków i rozciągać ich na całą grupę zawodową.

\section{Podsumowanie}

Normy poprawnościowe dotyczące leksyki religijnej i języka religijnego są przedmiotem zainteresowania korektorów i redaktorów językowych, a zainteresowanie to wynika z kilku czynników:

1. Redaktorzy odczuwają język religijny jako „specyficzny” - rządzący się swoimi prawami, mający własne normy poprawnościowe, czego wyrazem jest publikacja PSR, w wypadku języka religijnego ważniejsza nawet od WSO, tj. podstawowego źródła wiedzy o normie ortograficznej. Osoby te szukają potwierdzenia, że wybrane przez nie elementy językowe są zgodne ze specyfiką stylu religijnego.

2. Z jednej strony redaktorzy, podobnie jak inni użytkownicy języka, wykazują skłonność do nadużywania wielkiej litery (widać to nawet w pytaniu M/matkę T/teresę - jego autorka chce, co prawda, użyć małych liter, ale przyjmuje za podstawowy zapis !Matka Teresa zamiast matka Teresa); z drugiej - są świadomi, że wielka litera jest nadużywana, i chcą tych nadużyć uniknąć (zob. np. wypowiedź: ,Ja bym sugerowała jednak mniejszą miłość do dużych liter - zaczynamy nagminnie na wzór j. angielskiego używać ich wszędzie. Ja wiem, że jesteśmy pompatycznym narodem, ale może spuśćmy nieco powietrza, także z ortografii" - 28.09.2017). W języku religijnym wielkie litery pojawiają się częściej niż w tekstach stylistycznie neutralnych, gdyż

w tekstach religijnych pisanych przez wierzących $i$ adresowanych do ludzi wierzących (współwyznawców) kryterium znaczeniowe 
zwykle łączy się z uczuciowym, co upoważnia autora do stosowania wielkiej litery tam, gdzie samo kryterium znaczeniowe nie narzuca obligatoryjnie takiej pisowni (PSR, s. 9);

[...] każdy piszący może użyć wielkiej litery w przypadkach określonych w regułach 97, 98 i 99 WSO. Należy jednak pamiętać, aby tej swobody nie nadużywać, lecz korzystać z niej świadomie i odpowiedzialnie (PSR, s. 10-11);

redaktorzy chcą się upewnić, czy użycie przez nich wielkiej litery nie będzie nadużyciem, a użycie małej - brakiem zaznaczenia odpowiednich uczuć.

3. Występują rozbieżności między normą a uzusem oraz między poszczególnymi normami w różnych źródłach; redaktorzy szukają pomocy w ustaleniu, które ujęcie normy będzie najwłaściwsze.

4. Redaktorzy nie są pewni „statusu ontologicznego” danego elementu językowego lub kontekstu, w jakim on występuje - zgłaszają więc prośby o stosowną pomoc.

Na zakończenie dodajmy, że poddane analizie wypowiedzi pozwalają optymistycznie patrzeć na świadomość językową redaktorów i korektorów. Zasadniczo znają oni normy językowe, wiedzą, gdzie ich szukać, a w razie wątpliwości konsultują się z innymi osobami - koleżankami i kolegami po fachu. Zgłaszane wątpliwości wynikają nie z niskich kompetencji zawodowych, ale z braku odpowiednich norm, istnienia kilku norm obok siebie lub z trudności w ich interpretacji.

\section{Bibliografia}

Bajerowa I. (1994), Swoistość języka religijnego i niektóre problemy jego skuteczności, ,Łódzkie Studia Teologiczne” nr 3.

Ginter J. (2015), Pisownia stownictwa religijnego w internetowym poradnictwie językowym, „Język - Szkoła - Religia” nr 10 (4).

Ginter J. (2013), O pisowni wyrażenia , Ś/święty M/mikołaj” $i$ innych problemach ortograficznych w pracy redaktora podręczników do nauki języka polskiego w szkole podstawowej, „Język - Szkoła - Religia” nr 8 (2).

Ginter J. (2012), O klopotach z pisownia wyrażeń z komponentem „święty” na podstawie pytań i odpowiedzi zamieszczonych na stronach internetowych poradni językowych, „Język - Szkoła - Religia” nr 7 (1). 
Markowski A. (2009), Kultura języka polskiego. Teoria. Zagadnienia leksykalne, Warszawa.

[NSO] Nowy słownik ortograficzny PWN z zasadami pisowni i interpunkcji (1996), oprac. zasad pisowni i interpunkcji polskiej E. Polański, Warszawa.

[PSR] Przybylska R., Przyczyna W. (2011), Pisownia słownictwa religijnego, Tarnów.

Puzynina J. (1998), Problem kodyfikacji normy języka polskiego, https://rjp. pan.pl/index.php?option $=$ com_content\&view $=$ article\&id $=95$ :problem-kodyfika cji-normy-jzyka-polskiego\&catid $=45$.

Redaktorzy, korektorzy, edytorzy - taczcie się! (grupa na portalu Facebook), https://www.facebook.com/groups/478873322210758.

[SJP] Słownik języka polskiego PWN, https://sjp.pwn.pl.

Zdunkiewicz-Jedynak D. (2008), Wyktady ze stylistyki, Warszawa.

Zdunkiewicz-Jedynak D. (2006), ABC stylistyki, w: Polszczyzna na co dzień, red. M. Bańko, Warszawa.

[WSO] Wielki stownik ortograficzny PWN z zasadami pisowni i interpunkcji (wyd. 1 -2003; wyd. 2 - 2006; wyd. 3 - 2010; wyd. 4 - 2016), oprac. zasad pisowni i interpunkcji polskiej E. Polański, Warszawa.

[WSPP] Wielki stownik poprawnej polszczyzny PWN (2004), red. A. Markowski, Warszawa.

[ZPSR] Przybylska R., Przyczyna W. (red.) (2004), Zasady pisowni stownictwa religijnego, Tarnów.

\section{Streszczenie}

\section{Normy poprawnościowe dotyczące leksyki religijnej jako przedmiot zainteresowania korektorów i redaktorów językowych}

W artykule przedstawiono problemy poprawnościowe z zakresu słownictwa religijnego, jakie zgłaszają redaktorzy i korektorzy będący członkami samopomocowej grupy na Facebooku. Na podstawie tych pytań (wyrażonych w formie postów) i odpowiedzi na nie (komentarzy) wyciągnięto wnioski dotyczące znajomości norm językowych i ich źródeł wśród redaktorów, sposobów radzenia sobie z trudnościami językowymi oraz stosunku redaktorów do języka religijnego i leksyki religijnej.

Słowa kluczowe: redaktor, korektor, redakcja językowa, korekta, świadomość językowa, norma językowa, słownictwo religijne 


\section{Summary \\ Standards of correctness on the religious lexis as an object of interest for proofreaders and language editors}

The article presents problems of correctness in the field of religious vocabulary reported by editors and proofreaders who are members of a self-help group on Facebook. On the basis of these questions (expressed in posts) and the answers to them (comments), there were drawn conclusions about the knowledge (by editors) of linguistic norms and their sources, ways of solving the linguistic difficulties and the attitude of editors to religious language and religious lexis.

Keywords: editor, proofreader, language editing, proofreading, language awareness, language norm, religious lexis 